Pro memoria

\author{
Adam Bobryk \\ ORCID: 0000-0001-5876-4685 \\ adam.bobryk@uph.edu.pl \\ Uniwersytet Przyrodniczo-Humanistyczny w Siedlcach \\ Wydział Nauk Społecznych
}

\title{
Badacz polskiego wychodźstwa i Kresów Wschodnich - ks. prof. dr hab. Roman Dzwonkowski SAC (1930-2020)
}

DOI: $10.34739 /$ doc.2020.17.24

\begin{abstract}
W konsekwencji II wojny światowej ukształtowany został nowy ład polityczny. Kilkadziesiat lat funkcjonował system bipolarny. Polska znalazła się we wschodniej strefie wpływów, stając się częścią bloku podporządkowanego ZSRR. Konsekwencją tego była również zmiana granic, w wyniku których Kresy Wschodnie włączone zostały do Zwiazku Socjalistycznych Republik Radzieckich. Część ludności polskiej $z$ tych obszarów przesiedlono w nowe granice Rzeczypospolitej, poszerzone na zachodzie o tereny będace wcześniej częścia państwa niemieckiego. Wielu Polaków, którzy pozostali na Wschodzie, znalazło się w bardzo niekorzystnym położeniu. Przede wszystkim obniżył się ich status społeczny. W wyniku represji i przesiedleń zostali pozbawiani elit, w większości utracili swoją własność lub ograniczono możliwość dysponowania nią, $z$ ludności dominującej żyjącej we własnym państwie stali się narodowościa, umiejscowiona bardzo nisko w strukturze stratyfikacyjnej, zamieszkującej kraj poddajacy wszystkich obywateli silnej kontroli i indoktrynacji. Dążono w nim do marginalizacji znaczenia przynależności
\end{abstract}


narodowej, eliminacji życia religijnego oraz ukształtowania, jak to określano „człowieka radzieckiego”.

Stopień zależności ówczesnych władz Polski od ZSRR uniemożliwiał podejmowanie systemowych i znaczących interwencji dotyczących osób narodowości polskiej będących obywatelami radzieckimi. Polacy w Zwiazku Radzieckim praktycznie nie mogli realizować aktywności grupowej na rzecz swojej społeczności. Jedynie na Litwie funkcjonowały instytucje polskie jak media, oświata, amatorski ruch kulturalny, ale głównym ich zadaniem była indoktrynacja polityczna, przy uwzględnieniu ograniczonego zakresu specyfiki narodowej. Niemniej dawało to możliwość funkcjonowania języka polskiego w przestrzeni publicznej i grupowania się Polaków, a przez to ograniczało procesy asymilacji. Po 1948 r. (kiedy zlikwidowano ostatnie polskie placówki oświatowe na Białorusi i w Łotwie) oprócz Litwy (gdzie była sieć placówek), tylko na Ukrainie działała jedna szkoła polska. Oparcie instytucjonalne, w niewielkim możliwym zakresie, mniejszość polska mogła więc mieć jedynie w Kościele katolickim² ${ }^{2}$ Poddawany był on jednak licznym ograniczeniom i represjom ${ }^{3}$. Niemożliwe

1 Cf. Советское обшество и советский человек. Мифы и реальность. Сборник докладов Международной научно-практической конферениии, ред. С.И. Никонова (et al.), Казань 2012; А.В. Бузгалин, $\Lambda$.А. Бумавка, А.И. Колганов, СССР: оптилистическая трагедия. Причины возникновения и распада Советского Союза. Советская экономика, советское общество и советский Человек: противоречия, потенииал и уроки для России XXI века. Советская культура вызовы будушему. Мифы советской истории. СССР: незавершенный проект, Москва 2018; Н.П. Панков, Советский человек. Воспитание новой молодежи, 1920-1930-е годы, Москва 2019.

2 Jak oceniał ks. prof. Roman Dzwonkowski, polskość na terenie ZSRR przetrwała głównie „tam, gdzie istniały kościoły katolickie. (...) Nie było żadnych instytucji polskich, ale w kościołach ludzie modlili się i śpiewali po polsku i to był ten bastion, jeżeli już użyć tego słowa”. R. Dzwonkowski, Polacy na Wschodzie (wywiad przeprowadzony przez A. Bobryka), „Kurier Siedlecki”, 2 marca 1994.

${ }^{3}$ Szczególnie surowe represje były stosowane w okresie porewolucyjnym do końca rządów stalinowskich. Później one zelżały, ale nadal nie było swobody życia religijnego. Odnosząc się zwłaszcza do tego pierwszego okresu, ks. prof. Roman Dzwonkowski opisywał, iż wówczas masowo aresztowano duchownych, wielu zostało zgładzonych, zamykano świątynie, te które funkcjonowały obciązano bardzo wysokimi podatkami, powszechnie utrudniano lub uniemożliwiano wiernym realizację praktyk religijnych. Do 1939 r. doprowadzono do likwidacji Kościoła instytucjonalnego. Jak stwierdzał „Nie da się wyliczyć wszystkich form represji, bo stosowano wszystkie. Jakie dało się wymyśleć i realizować. Każda dziedzina życia, w tym sztuka, rozrywka, szkoła, wojsko, wszystkie środki masowego przekazu, były w służbie ateizacji”. Aneksja części terytorium Polski (1939), jak też inkorporacja Litwy i Łotwy, w sposób niezamierzony przez władze radzieckie, przyczyniły się do 
było wówczas również pełne dokumentowanie życia społecznego Polaków na Wschodzie, badanie tej problematyki, czy też podejmowanie działań popularyzujących. Niezwykle zawężone bowiem były możliwości kontaktu, a aktywność ta budziła zainteresowanie służb specjalnych, zwłaszcza KGB4 . W Polsce, poza nielicznymi wyjatkami uwzględniającymi ograniczenia ideologiczne, opracowania dotyczące tych zagadnień przed 1989 r. nie mogły uzyskać zgody cenzury na publikację. Materiały dotyczące życia mniejszości polskiej na Wschodzie ukazywały się tylko w wydawnictwach emigracyjnych, które miały jednak bardzo ograniczony dostęp zarówno do środowisk kresowych, jak też czytelników w Polsce.

Jednym z nielicznych badaczy, którzy docierali na Wschód, by dokumentować i analizować zachodzące wśród mniejszości polskiej procesy, był ks. prof. dr hab. Roman Dzwonkowski SAC5. Szczególne znaczenie ma fakt, iż jednocześnie niósł on posługę duszpasterską dla katolików, którzy mieli ze względów politycznych i administracyjnych bardzo ograniczony dostęp do możliwości praktyk religijnych. Zwłaszcza istotne jest to, że nie mógł działać legalnie. Zarówno proces badawczy, jak i posługa duszpasterska musiały być wykonywane w tajemnicy przed władzami. Aktywność ks. Dzwonkowskiego była zagrożona bardzo surowymi represjami. Funkcjonowanie w tych warunkach dawało mu jednak unikalna możliwość pomocy, jak też poznania zachodzacych procesów oraz dotarcia do środowisk niejednokrotnie bardzo hermetycznych. Zdobywał więc wiedzę i doświadczenie dotyczące statusu i położenia zarówno mniejszości polskiej oraz szerzej środowisk katolickich, co niemożliwe było dla innych badaczy. Jego determinacja, zaangażowanie, umiejętności i kompetencje nie tylko przyczyniły się do bieżącego wsparcia wielu

\footnotetext{
ponownego zaistnienia struktur kościelnych w ZSRR. Były one poddane różnym formom represji, ale dopuszczano ich funkcjonowanie w bardzo ograniczonym zakresie, przy jednoczesnym stałym dażeniu władz państwowych do ateizacji społeczeństwa. R. Dzwonkowski, Wiara w materię (wywiad przeprowadzony przez A. Bobryka), „Tygodnik Siedlecki”, 25 czerwca 1995.

4 Cf. K. Renik, Podpolnicy. Rozmowy z ludźmi kościoła na Litwie, Łotwie, Białorusi i Ukrainie 1990-1991, Warszawa 1991; P. Wołowski, K. Korzeniewska, Jak służac Panu Bogu, przechytrzyć KGB. Rozmowy z twórcami „Kroniki Kościoła Katolickiego na Litwie”, Warszawa 2006; A. Bobryk, KGB wobec zagrożeń systemu radzieckiego. Przykład rejonu trockiego w LSRR (1980-1984), „Rocznik Instytutu Europy Środkowo-Wschodniej” 2016, nr 14, z. 2, s. 35-65.

5 Posiadał on również drugie imię Jan, lecz go nie stosował.
} 
osób, ale przede wszystkim uchroniły one od zapomnienia ważny obszar rzeczywistości społecznej.

Ks. prof. dr hab. Roman Dzwonkowski SAC urodził się 30 listopada 1930 r. we wsi Dzwonek, położonej w gminie Czerwin. Po ukończeniu gimnazjum w Ostrołęce wstapił w 1948 r. do zakonu pallotynów (Stowarzyszenie Apostolstwa Katolickiego). Formację duchowa przechodził w Ołtarzewie, gdzie znajduje się zakonne seminarium duchowne. W 1957 r. uzyskał maturę w liceum dla pracujacych w Warszawie, a następnie przyjął święcenia kapłańskie. W okresie lat 1958-1961 studiował katolicka naukę społeczną na Katolickim Uniwersytecie Lubelskim. W latach 1966-1967 kształcił się także w Institut Catholique w Paryżu. Karierę naukowa zwiazał z Katolickim Uniwersytetem Lubelskim. Na tej uczelni uzyskał z socjologii doktorat (1966) i habilitację (1984). W 2001 r. otrzymał tytuł profesora. Prace jako wykładowca prowadził początkowo w Seminarium Duchownym w Ołtarzewie. Następnie od 1977 r. pracował w Katolickim Uniwersytecie Lubelskim. Najpierw w Instytucie Badań nad Polonia i Duszpasterstwem Polonijnym, a od 1989 r. był kierownikiem Katedry Socjologii Grup Etnicznych na Wydziale Nauk Społecznych. W latach 1994-2001 wykładał także w Seminarium Duchownym Diecezji Kamieniecko-Podolskiej w Gródku Podolskim (Ukraina) ${ }^{6}$. Wypromował dwoje doktorów ${ }^{7}$ oraz był recenzentem w 12 postępowaniach o nadanie stopnia doktora ${ }^{8}$. Działał w wielu instytucjach ukierunkowanych na badanie problematyki zwiazanej z Polakami żyjacymi poza granicami kraju oraz udzielających im wsparcia. W Polskiej Akademii Nauk był członkiem Komitetu Badań nad Migracjami Ludności i Polonią, w Polskiej Akademii Umiejętności

6 Ks. prof. dr hab. Roman Dzwonkowski SAC. Nota biograficzna, http://web.archive.org/web/20100204134105/http://www.kul.lublin.pl:80/dzwonkowski/ autor.html, (data dostępu: 31.12.2020). Szerzej działalność Katedry Socjologii Grup Etnicznych KUL i prowadzone przez nią badania zostały opracowane w publikacji: J. Plewko, Na zachodzie i na wschodzie - polonijne, etniczne i migracyjne zbiorowości $w$ perspektywie badawczej. Socjologia grup etnicznych, [w:] 100 lat socjologii w Katolickim Uniwersytecie Lubelskim Jana Pawła II, red. W. Szymczak, Lublin 2018, s. 201-225.

7 Adam Bobryk (2002), Agnieszka Grędzik (2003).

8 Jarosław Załęcki (1993), Jadwiga Plewko (1995), Robert Szwed (1999), Justyna Szulich-Kałuża (2001), Małgorzata Gałęziowska (2002), Henryk Manderla (2002), Norbert Wons (2002), Elżbieta Czapka (2004), Andrzej Wasilewski (2008), Pavel Zakševskij (2009), Eugeniusz Bogusz (2014), Jakub Osiecki (2015). 
wchodził w skład Komisji do Badań Diaspory Polskiej. Ponadto był członkiem Komisji Konferencji Episkopatu Polski ds. Duszpasterstwa Emigracji Polskiej i Rady Krajowej Stowarzyszenia „Wspólnota Polska”.

Pozostawił po sobie bardzo bogaty dorobek naukowy. Początkowo jego aktywność publicystyczna w latach 1974-1990 skupiona była na Polonii zachodniej, zwłaszcza francuskiej. Wśród kilkudziesięciu publikacji $z$ tego okresu niewątpliwie najważniejsza była monografia Polska opieka religijna we Francji 1909-19399. Późniejsze skoncentrowane były przede wszystkim na mniejszości polskiej na Wschodzie oraz funkcjonowaniu na tym obszarze Kościoła katolickiego ${ }^{10}$. Szczególną uwagę należy zwrócić tutaj na następujące publikacje: Za wschodnia granica 1917-199311, Polacy na dawnych Kresach Wschodnich. $Z$ problematyki narodowościowej $i$ religijnej12, Kościół katolicki w ZSSR 1917-1939. Zarys historï13, Losy duchowieństwa katolickiego w ZSSR 1917-1939. Martyrologium ${ }^{14}$, Postawy katolików obrzadku łacińskiego na Ukrainie wobec języka polskiego'15, Świadomość narodowa młodzieży polskiego pochodzenia $z$ byłego ZSRR studiujacej $w$ Polsce ${ }^{16}$, Leksykon duchowieństwa polskiego

9 R. Dzwonkowski, Polska opieka religijna we Francji 1909-1939, Poznań-Warszawa 1988.

10 Po latach ks. prof. dr hab. Edward Walewander oceniał zmianę tego kierunku zainteresowania badawczego następująco „Z perspektywy lat należy doprawdy pogratulować wyczucia, bo warto było zrobić ten długi krok znad Sekwany aż nad Wołge. Na Wschodzie wiele spraw ludzkich leżało zagrzebanych nie tylko w niepamięci czy też w pamięci stale jeszcze sterroryzowanej i zafałszowanej. Ksiądz Profesor wiele się natrudził, aby tę pamięć odkopać czy też ośmielić przechowujacych ja świadków i sprawić, by stała się świadectwem. To wielka zasługa Księdza Profesora. $Z$ pewnościa inni napisza o tym jeszcze bardzo wiele, trzeba jednak od razu stwierdzić, że tych ginacych świadectw nikt by już za jakiś czas nie zdołał uratować. Ks. prof. Roman Dzwonkowski uczynił to $z$ wielkim powodzeniem. E. Walewander, Roman Dzwonkowski SAC. Kustosz pamięci Polaków na „nieludzkiej ziemi”, mps skierowany do publikacji w „Naszym Dzienniku”.

${ }^{11}$ R. Dzwonkowski, Za wschodnia granica 1917-1993. O Polakach i Kościele w dawnym ZSRR (wywiad przeprowadzony przez J. Pałygę), Warszawa 1993.

12 R. Dzwonkowski, Polacy na dawnych Kresach Wschodnich. Z problematyki narodowościowej i religijnej, Lublin 1994.

13 Idem, Kościót katolicki w ZSSR 1917-1939. Zarys historii, Lublin 1997.

14 Idem, Losy duchowieństwa katolickiego w ZSSR 1917-1939. Martyrologium, Lublin 1998.

15 Idem, O. Gorbaniuk, J. Gorbaniuk, Postawy katolików obrzadku łacińskiego na Ukrainie wobec języka polskiego, Lublin 2001.

16 R. Dzwonkowski, O. Gorbaniuk, J. Gorbaniuk, Świadomość narodowa młodzieży polskiego pochodzenia $z$ byłego ZSRR studiujacej w Polsce, Lublin 2002. 
represjonowanego $w$ ZSRS 1939-198817, Mniejszości narodowe a ewangelizacja. Białoruś - Ukraina ${ }^{18}$, Postawy wobec języka polskiego katolików obrzadku łacińskiego na Białorusi ${ }^{19}$, Jan Paweł II do Polonii i Polaków za granica 1979-200320, Religia i Kościół katolicki wZSRS 1917-1991. Kronika ${ }^{21}$, Polacy w Kościele katolickim na Wschodzie (1939-2011)22, Papież Jan Paweł II. Spotkania z Polakami na Wschodzie (1993, 1999, 2001, 2002)23, Od „Kościoła polskiego” do „Kościoła Polaków” na Wschodzie ${ }^{24}$. Był także redaktorem wielu prac zbiorowych, z których należy wskazać m.in. Skazani jako „szpiedzy Watykanu". Z historii Kościoła katolickiego w ZSRR 1917-195625, Listy $z$ więzien, łagrów i zesłania do Delegatury PCK $w$ Moskwie 1924-193726, Głód i represje wobec ludności polskiej na Ukrainie 19321947. Relacje27, Papież Jan Pawet II do Polonii i Polaków za granica 1979-2003. Przemówienia. Listy. Telegramy28. Ponadto opublikował wiele artykułów w wydawnictwach naukowych w Polsce i za granica.

Od 1970 r. wyjeżdżał do ZSRR. Głównie do Białorusi, Litwy, Łotwy, Ukrainy, Gruzji i Rosji. Oficjalnie były to wizyty na zaproszenie osób prywatnych. Faktycznie w tym czasie prowadził nielegalna pracę duszpasterska oraz realizował badania wśród społeczności polskiej, a także szerzej wśród wiernych Kościoła rzymskokatolickiego. Materiały będące efektem tych wyjazdów publikował od

17 R. Dzwonkowski, Leksykon duchowieństwa polskiego represjonowanego $w$ ZSRS 1939-1988, Lublin 2003.

18 Idem, Mniejszości narodowe a ewangelizacja. Białoruś - Ukraina, Lublin 2004.

19 Idem, O. Gorbaniuk, J. Gorbaniuk, Postawy wobec języka polskiego katolików obrzadku łacińskiego na Białorusi, Lublin 2004.

20 R. Dzwonkowski, Jan Paweł II do Polonii i Polaków za granica 1979-2003, Ząbki 2008.

${ }^{21}$ Idem, Religia i Kościół katolicki w ZSRS 1917-1991. Kronika, Lublin 2010.

22 Idem, Polacy w Kościele katolickim na Wschodzie (1939-2011), Torun 2011.

23 Idem, Papież Jan Paweł II. Spotkania z Polakami na Wschodzie (1993, 1999, 2001, 2002), Lublin 2012.

24 Idem, Od „Kościoła polskiego” do „Kościoła Polaków” na Wschodzie, Warszawa 2017.

25 Skazani jako „szpiedzy Watykanu”. Z historii Kościoła katolickiego w ZSRR 1917-1956, red. R. Dzwonkowski, Zabki 1998.

26 Listy z więzień, łagrów i zesłania do Delegatury PCK w Moskwie 1924-1937, red.

R. Dzwonkowski, Lublin 2001.

27 Głód i represje wobec ludności polskiej na Ukrainie 1932-1947. Relacje, red.

R. Dzwonkowski, Lublin 2004.

28 Papież Jan Pawet II do Polonii i Polaków za granica 1979-2003. Przemówienia. Listy. Telegramy, oprac. R. Dzwonkowski, Ząbki 2007. 
1973 r. pod pseudonimami w polskiej prasie emigracyjnej29. $\mathrm{Na}$ szczególną uwagę zasługuje zwłaszcza artykuł Polacy, Litwini, Białorusini w paryskiej „Kulturze”, podpisany pseudonimem P. Lida ${ }^{30}$. Pierestrojka ${ }^{31} \mathrm{w}$ ZSRR (zapoczątkowana w 1985 r.), a następnie rozpad tego państwa 32 (1991 r.) umożliwiły swobodną aktywność mniejszości polskiej, organizowanie życia religijnego, prowadzenie badań z dostępem do archiwów zawierających materiały służb specjalnych oraz sądownictwa, co w znacznym stopniu dało szansę odtworzenia wielu ważnych aspektów historii, ukazując ją w kontekście społecznym. Przemiany demokratyczne w Polsce, dokonane na przełomie lat 80. i 90. stworzyły zaś szerokie możliwości wspierania rodaków poza granicami kraju, rozwijania badań dotyczących ich położenia oraz upowszechniania publicystyki $z$ tym związanej. Ksiądz profesor Roman Dzwonkowski był bardzo ważnym uczestnikiem tych działań ${ }^{33}$.

Dużo wymagał zarówno od siebie, jak też od innych. Nie wszyscy współpracownicy byli w stanie sprostać tym oczekiwaniom. Nie stosował taryf ulgowych. Oczekiwał solidnej pracy i wnikliwych badań, które poddawał starannej weryfikacji. Wielokrotnie podkreślał, iż praca naukowa nie może być napisana od razu lecz musi mieć solidne podstawy i być wielokrotnie poprawiana. Zalecał unikanie emocjonalnego zaangażowania, gdyż zaburzałoby to proces poznawczy. Weryfikowanie, konfrontowanie danych, poszukiwanie nowych źródeł - to dla niego nie była teoria. Nie podejmował łatwych zagadnień. Celem, który wskazywał było wszechstronne poznanie analizowanego problemu $z$ całym towarzyszacym mu kontekstem. Wyjazdy terenowe, kontakty $z$ uczestnikami wydarzeń, praca $\mathrm{w}$ archiwach, wykorzystywanie szeregu narzędzi badawczych przynosiło świetne rezultaty. Dzięki niemu nie tylko zostało opracowanych, a poprzez to ocalonych od zapomnienia, wiele ważnych aspektów $z$ zakresu

\footnotetext{
29 K. Bojko, Odszedł ks. prof. Roman Dzwonkowski SAC, https://www.kul.pl/odszedlks-prof-roman-dzwonkowski-sac,art_92992.html, (data dostępu: 31.12.2020).

30 P. Lida [R. Dzwonkowski], Polacy, Litwini, Białorusini, „Kultura” 1980, nr 1-2, s. 35-62.

31 M. Schmitt, Das Ostgeschäft von morgen. Glasnost-Perestoika-Uskorenje, Baden-Baden 1988.

32 M. Malek, A. Schor-Tschudnowskaja, Der Zerfall der Sowjetunion. Ursachen Begleiterscheinungen - Hintergründe, Baden-Baden 2013.

33 Ks. prof. dr hab. Roman Dzwonkowski nie tylko zajmował się działalnościa naukowa, ale również popularyzatorska poprzez liczne publikacje i wystapienia w środkach społecznego przekazu.
} 
funkcjonowania mniejszości narodowych czy Polaków poza granicami kraju oraz życia Kościoła w warunkach ograniczeń społecznopolitycznych. Przede wszystkim wniósł nowe elementy do rozwoju socjologii. Za swoja pracę uzyskał wiele wyróżnień i nagród. Niewątpliwie jedna $z$ najważniejszych było odznaczenie go w 2010 r. przez prezydenta Bronisława Komorowskiego Krzyżem Komandorskim Orderu Odrodzenia Polski za wybitne zasługi dla Polonii na świecie, za promowanie Polski oraz działalność na rzecz krzewienia polskich tradycji i kultury ${ }^{34}$.

Bardzo symptomatyczne sa słowa sekretarza stanu w Ministerstwie Spraw Zagranicznych, Jana Dziedziczaka, wygłoszone w 2017 r., kiedy to wyraził opinię „Publikacje Ks. Prof. Romana Dzwonkowskiego o Polakach na Wschodzie (...) stanowia fundamentalny przewodnik po problematyce polonijnej i sa wykorzystywane przez kolejne pokolenia urzędników administracji rządowej. Powstawały jako efekt badań prowadzonych w bezpośrednim kontakcie $z$ ludźmi - ich bohaterami. Ks. Prof. Roman Dzwonkowski nie tylko zbierał materiały do swych badań, niósł także posługę duszpasterską w języku polskim (...). Jego praca stanowiła i wciąż stanowi intelektualna podstawę dla starań polskiej dyplomacji o zapewnienie należytego rozwoju języka polskiego, w szczególności na Wschodzie. Także jego społeczna aktywność w wielu środowiskach polskich wspomagała ich umocnienie"35. To bardzo ważna ocena. Odzwierciedla ona pewną tendencję szerokiego uznania dla zasług badawczych ks. prof. Romana Dzwonkowskiego. Do końca prowadził pracę naukowa, publikował i aktywnie interesował się obszarem badawczym, któremu poświęcił całe życie. Zmarł 30 grudnia 2020 r. w Lublinie. Przeżył 90 bardzo owocnych lat. Jak stwierdzał ks. prof. dr hab. Edward Walewander: „Publikacje ks. prof. Dzwonkowskiego sa wysoko cenione w krajowych i zagranicznych środowiskach naukowych. Mają też szerokie grono czytelników w Polsce i w krajach, których dotyczyły zrelacjonowane w nich badania. Budza duże zainteresowanie, bo poruszana w nich problematyka przez długi czas była mało znana, a nawet wręcz zakazana. Zmarły był jednym $z$

${ }^{34}$ Postanowienie Prezydenta Rzeczypospolitej Polskiej z dnia 14 października 2010 r. o nadaniu orderów i odznaczeń, „Monitor Polski” 2011, nr 11, poz. 113.

35 R. Dzwonkowski, Od „Kościoła polskiego”..., s. 25. 
pionierów, którzy się nią zajęli. I to pionierem nader odważnym, szukającym skutecznych sposobów dotarcia do niedostępnych źródeł i przez dziesiątki lat zastraszonych świadków"36. Jednocześnie ks. E. Walewander bardzo trafnie podsumował działalność i życie ks. prof. dr hab. Romana Dzwonkowskiego, stwierdzajac, iż był on kustoszem pamięci Polaków na nieludzkiej ziemi ${ }^{37}$.

Bibliografia / References

Bobryk A., KGB wobec zagrożeń systemu radzieckiego. Przykład rejonu trockiego w LSRR (1980-1984), „Rocznik Instytutu Europy Środkowo-Wschodniej” 2016, nr 14, z. 2.

Bojko K., Odszedł ks. prof. Roman Dzwonkowski SAC, https://www.kul. pl/odszedl-ks-prof-roman-dzwonkowski-sac, art_92992.html, (data dostępu: 31.12.2020).

Buzgalin A.V., Bulavka L.A., Kolganov A.I., SSSR: optimističeskaâ tragediâ. Pričiny vozniknoveniâ iraspada Sovetskogo Soûza. Sovetskaâ èkonomika, sovetskoe obŝestvo isovetskij Čelovek: protivorečiâ, potencial i uroki dlâ Rossii XXI veka. Sovetskaâ kul'tura-vyzovy buduŝemu. Mify sovetskoj istorii. SSSR: nezaveršennyj proekt, Moskva 2018, [Бузгалин А.В., Булавка А.А., Колганов А.И., СССР: оптимистическая трагедия. Причины возникновения и распада Советского Союза. Советская экономика, советское обиество и советский Человек: противоречия, потенииал и уроки для России XXI века. Советская культура - вызовы будушему. Мифы советской истории. СССР: незавершенный проект, Москва 2018].

Dzwonkowski R., Gorbaniuk O., Gorbaniuk J., Postawy katolików obrzadku łacińskiego na Ukrainie wobec języka polskiego, Lublin 2001.

Dzwonkowski R., Gorbaniuk O., Gorbaniuk J., Postauy wobec języka polskiego katolików obrządku łacińskiego na Białorusi, Lublin 2004.

Dzwonkowski R., Gorbaniuk O., Gorbaniuk J., Świadomość narodowa młodzieży polskiego pochodzenia $z$ byłego ZSRR studiujacej $w$ Polsce, Lublin 2002.

Dzwonkowski R., Jan Paweł II do Polonii i Polaków za granica 1979-2003, Ząbki 2008.

36 E. Walewander, Roman Dzwonkowski SAC...

37 Ibidem. 
Dzwonkowski R., Kościół katolicki w ZSSR 1917-1939. Zarys historii, Lublin 1997.

Dzwonkowski R., Leksykon duchowieństwa polskiego represjonowanego w ZSRS 1939-1988, Lublin 2003.

Dzwonkowski R., Losy duchowieństwa katolickiego w ZSSR 1917-1939. Martyrologium, Lublin 1998.

Dzwonkowski R., Mniejszości narodowe a ewangelizacja. Białoruś Ukraina, Lublin 2004.

Dzwonkowski R., Od „Kościoła polskiego” do „Kościoła Polaków” na Wschodzie, Warszawa 2017.

Dzwonkowski R., Papież Jan Paweł II. Spotkania z Polakami na Wschodzie (1993, 1999, 2001, 2002), Lublin 2012.

Dzwonkowski R., Polacy na dawnych Kresach Wschodnich. $Z$ problematyki narodowościowej i religijnej, Lublin 1994.

Dzwonkowski R., Polacy na Wschodzie (wywiad przeprowadzony przez A. Bobryka), „Kurier Siedlecki”, 2 marca 1994.

Dzwonkowski R., Polacy w Kościele katolickim na Wschodzie (1939-2011), Toruń 2011.

Dzwonkowski R., Polska opieka religijna we Francji 1909-1939, PoznańWarszawa 1988.

Dzwonkowski R., Religia i Kościół katolicki w ZSRS 1917-1991. Kronika, Lublin 2010.

Dzwonkowski R., Wiara $w$ materie (wywiad przeprowadzony przez A. Bobryka), „Tygodnik Siedlecki”, 25 czerwca 1995.

Dzwonkowski R., Za wschodnia granica 1917-1993. O Polakach $i$ Kościele $w$ dawnym ZSRR (wywiad przeprowadzony przez J. Pałyge), Warszawa 1993.

Głód i represje wobec ludności polskiej na Ukrainie 1932-1947. Relacje, red. R. Dzwonkowski, Lublin 2004.

Ks. prof. $d r$ hab. Roman Dzwonkowski SAC. Nota biograficzna, http://web.archive.org/web/20100204134105/http://www.kul.lublin.pl:80/dzwonkowski/autor.html, (data dostępu: 31.12.2020).

Lida P. [Dzwonkowski R.], Polacy, Litwini, Białorusini, „Kultura” 1980, nr 1-2.

Listy $z$ więzień, łagrów i zesłania do Delegatury PCK $w$ Moskwie 1924-1937, red. R. Dzwonkowski, Lublin 2001.

Malek M., Schor-Tschudnowskaja A., Der Zerfall der Sowjetunion. Ursachen - Begleiterscheinungen - Hintergründe, Baden-Baden 2013.

Pankov N.P., Sovetskij čelovek. Vospitanie novoj molodeži, 1920-1930-e gody, Moskva 2019, [Панков Н.П., Советский человек. Воспитание новой молодежи, 1920-1930-е годы, Москва 2019]. 
Papież Jan Paweł II do Polonii i Polaków za granica 1979-2003. Przemówienia. Listy. Telegramy, oprac. R. Dzwonkowski, Ząbki 2007.

Plewko J., Na zachodzie i na wschodzie - polonijne, etniczne i migracyjne zbiorowości $w$ perspektywie badawczej. Socjologia grup etnicznych, [w:] 100 lat socjologii w Katolickim Uniwersytecie Lubelskim Jana Pawła II, red. W. Szymczak, Lublin 2018.

Postanowienie Prezydenta Rzeczypospolitej Polskiej z dnia 14 października 2010 r. o nadaniu orderów i odznaczeń, „Monitor Polski” 2011, nr 11, poz. 113.

Renik K., Podpolnicy. Rozmowy z ludźmi kościoła na Litwie, Łotwie, Białorusi i Ukrainie 1990-1991, Warszawa 1991.

Schmitt M., Das Ostgeschäft von morgen. Glasnost-Perestoika-Uskorenje, Baden-Baden 1988.

Skazani jako „szpiedzy Watykanu”. Z historii Kościoła katolickiego w ZSRR 1917-1956, red. R. Dzwonkowski, Zabbki 1998.

Sovetskoe obŝestvo isovetskij čelovek. Mify i real'nost'. Sbornik dokladov Meždunarodnoj naučno-praktičeskoj konferencii, red. S.I. Nikonova (et al.), Kazan' 2012, [Советское общество и советский человек. Мифы и реальность. Сборник докладов Межљуннародной научно-практической конферениии, red. С.И. Никонова (et al.), Казань 2012].

Walewander E., Roman Dzwonkowski SAC. Kustosz pamięci Polaków na „nieludzkiej ziemi”, mps skierowany do publikacji w „Naszym Dzienniku”. 
